UDC 629.4-592

M. I. Gorbunov ${ }^{1}$, Dr. Sc. (Tech.), Prof., orcid.org/0000-0002-8556-3392,

O.V. Fomin ${ }^{2}$, Dr. Sc. (Tech.), Assoc. Prof., orcid.org/0000-0003-2387-9946,

O. V. Prosvirova ${ }^{1}$, Cand. Sc. (Tech.), orcid.org/0000-0002-7034-8622,

P. M. Prokopenko ${ }^{2}$, orcid.org/0000-0002-1631-6590
DOI: $10.29202 /$ nvngu/2019-2/5

1 - Volodymyr Dahl East Ukrainian National University, Severodonetsk, Ukraine, e-mail: gorbunov0255@gmail.com; prosvirova@ ukr.net

2 - State University of Infrastructure and Technology, Kyiv, Ukraine, e-mail: fomin1985@ukr.net; prokopenko1520mm@ gmail.com

\title{
CONCEPTUAL BASIS OF THERMO-CONTROLLABILITY IN RAILWAY BRAKING TRIBO PAIRS
}

Nowadays, the problem of insufficient braking power is solved by increasing the number of friction pairs, resulting in an increase in resource and labor intensity, unsprung mass, resistance to movement, and low resource efficiency. Also acute is the problem of reducing the noise level when using friction brakes. The analysis of the problems of existing brake equipment led to the choice of a promising direction of research on the effectiveness of braking - control of the temperature of the brake friction surfaces.

Purpose. To create a method for increasing the efficiency of the braking system by controlling the cooling of the friction surfaces by adaptive air supply; to create a mathematical model of air pressure supply to the brake frictional contact in order to obtain the optimal diameter of friction lining holes and the air feed rate.

Methodology. During the research, the analysis of leading modern studies and patents of technical solutions aimed at improving the frictional properties of brake devices, methods of decision-making theory and expert evaluation of methods for improving the operational characteristics of railway braking systems is conducted. Mathematical modeling of air pressure supply to the zone of relevant frictional contact is applied.

Findings. A concept of adaptive energy consumption management at self-ventilation of a brake disc plate using the improved mathematical model which considers geometric parameters of air courses. A method for assessing the influence of the factors on brake equipment operation while supplying the compressed air to the frictional contact is suggested.

Originality. The mathematical model of air pressure supply to brake frictional contact is developed in order to obtain the optimal diameter of the friction lining holes. Application of the suggested technique for cooling will allow advancing efficiency of operation of frictional braking elements of rolling stock, increasing the adhesive coefficient, stabilizing the temperature in the tribo-contact, decreasing the wear of brake surfaces of friction and increasing safety of operation.

Practical value. As a result of the conducted research complex, the method of adaptive forced cooling of the friction surfaces of the brake was proposed and scientifically substantiated for the first time, which will provide effective characteristics of the cooling process, will allow reducing significantly the dependence of the coefficient of friction on the temperature in the contact zone of the working elements during braking. The application of the proposed developments will allow:

- using the compressed air, which is drawn from the brake cylinders, effectively;

- cooling the contact area of "brake pad - wheel", "brake pad - disk", by supplying compressed cooled air into the holes of the brake pad or formation in the contact zone of the active gaseous medium;

- increasing braking efficiency and reducing the intensity of wear of the brake pads due to the timely removal of friction wear from the contact area;

- increasing the rail traffic safety by enhancing the reliability of braking.

Keywords: railway transport, thermo-controllability, disk brakes, friction interaction

Introduction. The problem of ensuring the efficiency and safety of the braking of rolling stock is exacerbated by the increase in the speed of rail transport in Ukraine and in the world. A significant increase in kinetic energy, which affects the temperature rise of the friction elements of the brakes during braking, necessitates the development of the scientific basis of thermo chemistry in the rail brake tribopairs, the study of new methods for improving the brake characteristics of the rolling stock of railways.

Consequently, there is an urgent task to create a method for improving the efficiency of the braking sys-

(C) Gorbunov M. I., Fomin O. V., Prosvirova O. V., Prokopenko P. M., 2019 tem that will provide effective characteristics of the cooling process, will significantly reduce the dependence of the coefficient of friction on the temperature generated in the contact zone of the working elements during braking.

Analysis of the recent research and unsolved aspects of the problem. The analysis of the results of an expert survey within the framework of the study of the International Union of Railways has led to the processing of about 100 questionnaires of industry researchers from participating countries, representing individual research experience, along with experience in addressing specific tasks of the railway industry in their countries, showed 
that the following directions of development of railway transport were the most demanded:

1. Resistant construction of rolling stock ("Rolling stock" cluster).

2. Traffic safety and personal safety of passengers ("System as a whole" cluster) [1].

3. Technologies for monitoring the rolling stock and compatibility ("Infrastructure" cluster).

4. Development of new materials and technologies for the infrastructure ("Infrastructure" cluster).

5 . New materials and production processes for rolling stock ("Rolling stock" cluster).

6 . Interaction in the wheel-rail system ("Infrastructure" cluster) [2].

Analyzing the 6 most priority areas of research, one can distinguish the pattern with the highest concentration and demand directions within the framework of scientific clusters of Infrastructure and Rolling Stock. Experts-specialists determine the reliable and safe operation of the infrastructure and rolling stock as the basis for efficient operation of the railway transport complex.

The effectiveness of brake facilities is one of the most important conditions that determine the possibility of increasing the weight and speed of trains, the train-handling and freight capacity of railways. From the properties and condition of the brake equipment of the rolling stock, to a great extent, the safety of the movement depends.

Due to the constant increase in the speed of trains, high requirements for braking devices are imposed. The application of the well-known design of the brake shoe, which involves the interaction of the brake pad with the wheel surface, is limited by the limits of their permissible heating. The use of disc brakes is becoming more widespread, because the required braking power is not achieved with the help of shoe brakes. The use of shoe brakes at high speeds is also undesirable due to the fact that the wear of the wheels increases significantly.

In the course of operation, the surface of the riding and the rudder of the running wheels interact with the rails, and in the case of clutch braking - with the blocks on the brake axles as well. As a result, both friction pairs mutually influence the process of wearing the wheels and rails, forming a contact zone between them and the level of contact stresses that arise, and, consequently, on the coupling forces that determine the size of the traction and braking forces of the rolling stock.

Modern world studies on improving the effectiveness of friction interaction consist of work on the following main areas:

- mathematical modeling of thermophysical and mechanical processes in the zone of friction contact in the wheel-brake system, required for the analysis of existing and advanced brake equipment [3];

- assessment of reliability and technical risks of operation of brake equipment [4];

- computer simulation of thermophysical and mechanical processes in the zone of frictional contact of brake elements using finite element models and analysis of its results $[5,6]$;
- research on computational hydro-gas dynamics;

- experimental studies of friction processes with cyclic temperature stabilization at high speed;

- development of devices aimed at controlling friction processes, including those for the improvement of brake devices.

The process of breaking of the rolling stock is significant influenced by dynamic forces. In this case, special attention is paid to improving the methodology [7, 8] to determine the appropriate effort. Also, [9] promising directions for improvement of the respective qualities of freight wagons are currently proposed, and some [10] separate positive results are presented.

Among the modern studies, a significant place is occupied by the research on thermal stresses of disc brakes, in particular the study of dynamic loads [11], research on the ventilation apparatus of brake discs, analysis of the mechanisms of heat transfer of brake friction elements [12].

The need to supplement existing research does not call into question the characteristics of the friction processes presented in the studies. The authors of the works point to the need to ensure a stable coefficient of friction of the friction surfaces, reduce the temperature and reduce the probability of occurrence of wheel sliding. Consequently, based on the world's leading research, the task is to develop a scientific basis for thermo coupling in the rail brake tribopairs and effective methods for improving the brake friction system in order to increase the braking performance by controlling the temperature in the friction pair.

Objectives of the article. Definition and substantiation of the most effective methods of perfection of the brake friction system in order to increase the braking efficiency by controlling the temperature in the friction pair, increasing the thermoregulation and energy dissipation capacity in the braking systems. Creation of a method for increasing the efficiency of the braking system by controlling the cooling of the friction surfaces by adaptive air supply; the creation of a mathematical model of the dependence of the optimal diameter of the friction lining holes on the air pressure supplied in them, the air expenditure from the pressure and the method for assessing the influence of factors on the operation of the braking equipment during the supply of compressed air to the frictional contact.

Research methodology. Presentation of the main research. The main idea of the proposed approaches is to study the question raised in the article using the method of expert evaluations.

The method of expert evaluations allows working with insufficiently formalized and structured tasks, which are not clearly defined as algorithms, properties and relations. The ease of use of the expert estimation method, its flexibility and the ability to obtain the necessary information led to its use to assess the options for improving the braking system elements to stabilize the temperature in tribo-contacts. The group of experts included scientists and engineers from universities, depot and manufacturers of rolling stock components. The factors for evaluating innovative methods for increasing 
the efficiency of the braking system of the modern rolling stock are as follows:

- increased security;

- stable friction characteristics (coefficient of friction, temperature);

- wear resistance;

- noise level during braking;

- cost of construction and operation;

- ecological factor.

Setting up the task of expert evaluation involves:

1. The object of the research - braking systems.

2. The number of options proposed by experts $n$.

3. The evaluation of options involves m experts.

4. Each expert has his rank, which is determined by the level of his competence and sources of assessment arguments.

5. Each expert conducts a qualitative assessment of the proposed options.

6. All variants of improvement of brake elements should be distributed in order of importance.

Innovative methods for increasing the efficiency of the braking system of the modern rolling stock are as follows:

IM1 - forced air supply to the contact of triboelements;

IM2 - forced air supply, the temperature of which is regulated depending on conditions and modes of operation;

IM3 - application of pads with powdered inserts;

IM4 - application of pads with cooling ribs;

IM5 - application of brake linings whose outer surface is made of heat-dispersing material;

IM6 - supply to the contact area of triboelements of friction activators;

IM7 - the application of brake elements the construction of which provides for phase transitions.

The processing of the results of the expert evaluation was carried out with the help of the program developed by the authors (Table).

As a result of the conducted expert research, the estimation of innovative methods for increasing the effi-

Table

Statistical analysis of the results

\begin{tabular}{|c|c|c|c|c|c|}
\hline Factor & 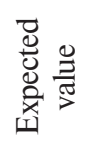 & 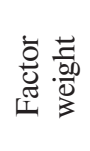 & . & 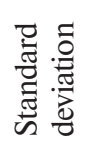 & 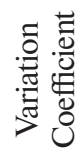 \\
\hline 1 & 4.909 & 0.175 & 2 & 0.905 & 18.4 \\
\hline 2 & 6.636 & 0.237 & 1 & 0.651 & 9.8 \\
\hline 3 & 4.273 & 0.153 & 1 & 0.603 & 14.1 \\
\hline 4 & 3.182 & 0.114 & 2 & 0.778 & 24.5 \\
\hline 5 & 4.273 & 0.153 & 3 & 1.168 & 27.3 \\
\hline 6 & 3.273 & 0.117 & 2 & 1.015 & 31 \\
\hline 7 & 5.455 & 0.195 & 1 & 0.674 & 12.4 \\
\hline \multicolumn{2}{|c|}{$\begin{array}{l}\text { Coordination } \\
\text { factor }=0.4\end{array}$} & & & & \\
\hline
\end{tabular}

ciency of the braking system of the modern rolling stock has been evaluated. It has been established that the most promising method for increasing the braking efficiency is the supply of air with adjustable temperature, depending on braking and operating conditions. This method received the highest rank of 0.237 . However, other methods can also be considered promising, since the difference in estimates is negligible. According to experts' opinion, the slightest effect on temperature stabilization has the edges of cooling pads (the sum of ranges is 0.114 ).

On the basis of the analysis of leading modern research studies and patents of technical solutions aimed at improving the frictional properties of brake tools, the following classification of methods for the implementation of thermoregulatory and energy dissipation functions in braking systems has been developed.

1. Thermal regulation is based on the absorption or allocation of heat by metallic or non-metallic friction elements of brake devices. In this case, you can use:

1.1. Chemical reactions to materials of friction overlays with release or absorption of heat.

1.2. Effects of allocation and absorption of energy when the aggregate state of friction elements changes (melting, evaporation, sublimation, crystallization, and others).

1.3. Physical properties of materials of friction elements, which provide high heat output.

2. The thermoregulation is based on the removal of heat outside of the friction pair of friction elements:

2.1. Ventilation and self-ventilation.

2.2. Extraction of heat with special cooling elements.

The analysis of the results of the processing of expert data indicates that, according to experts, the most effective methods are cooling of frictional contact, improvement of the ventilation device of disc brakes.

This task can only be performed on the basis of new scientific and technical solutions in the field of brake equipment, which will allow the creation of a system of forced cooling of the disc brakes, which will provide effective characteristics of the cooling process, will have acceptable mass-dimensional and fire performance and significantly reduce the dependence of the coefficient of friction on temperature generated in the contact zone of the working elements during braking.

Method of cooling the brake frictional contact by supplying compressed air. The mechanical part of the disc brakes of the freight car consists of brake discs, which are pressed by two on each wheel set, brake linings and brake blocks (Fig. 1).

Working braking is carried out by disc brake, which consists of brake blocks (Fig. 2) fixed by means of bolted connections to the transverse beams frame brackets cart. Brake blocks consist of case 1 (Fig. 2) respectively, and tick-borne mechanisms. The inner levers of the caliper are pivotally connected according to the rod and casing brake cylinder longitudinal rods. Tick-borne mechanism consists of two levers and 8-tightening divider 7, 6 shoe, brake linings 5 and 4, nuts, washers and pins. With pincers-like mechanisms, bilateral arrangements are made to effect brake linings, brake discs, mounted on 

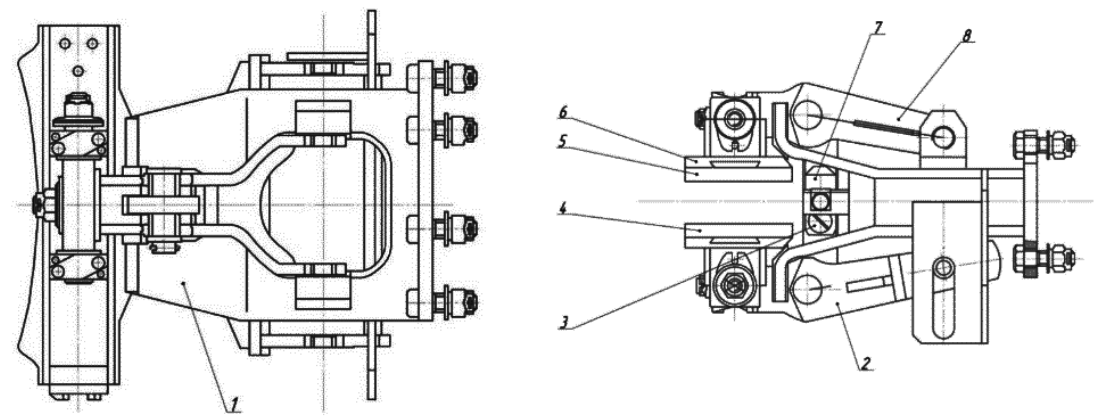

Fig. 1. The brake block

axes wheel sets. The pulling divider that works as hard rod and gear lever effort from one to another, moving them toward the brake disk, simultaneously provides uniform gaps between the pads and the disc brakes with vacation. Fixing levers of a pincer-like mechanism with skids is configured to move them in two mutually perpendicular directions, providing uniform pressing of the brake pads to the brake disc surface. The brake linings are installed in the guide holders and closed with a blocking bolt that is restrained by a locking spring. On both wheel pairs of bogies, two brake discs are installed (Fig. 2).

The proposed method of railway vehicle braking and equipment for its implementation is as follows.

Compressor 1 pumps compressed air into the main tank 2; the air goes to the crane driver 4 along the feed line 3 . The crane driver connects the main tanks 2 and feed line 3 from brake manifold 5 .

Before the train is sent, brake is charged; for this reason, the handle of the crane driver 4 is put in the selling position (Fig. 3), in which air from the main reservoir 2 enters the brake lines 5 through the feed line 3 via the crane driver 4 and then through the air distributor $6-$ in the reserve tank 8 . At the same time, through the air distributor 6 and a check valve 10, the brake cylinder 7

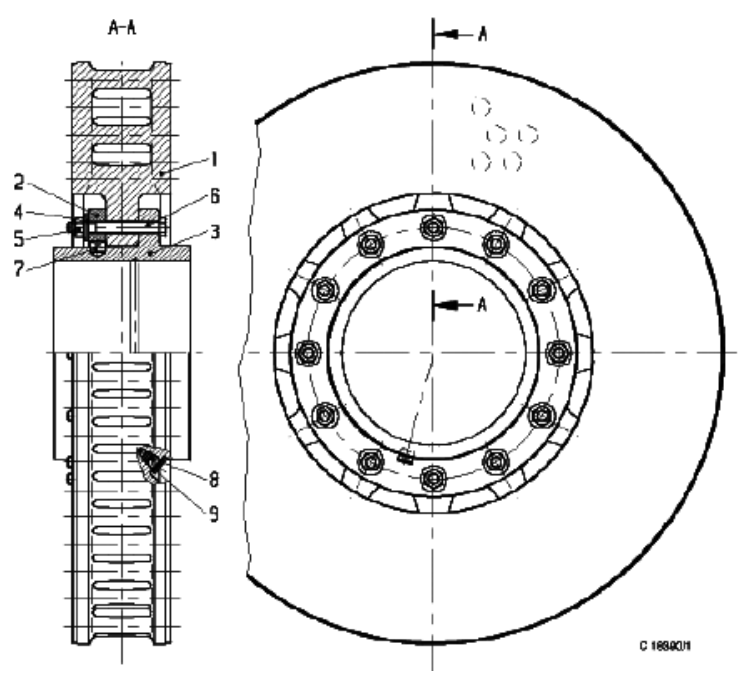

Fig. 2. Vented brake disc:

1 - friction ring; 2 - clamping ring; 3 - hub; 4-washer or clamping sleeve; 5 - lock nuts; 6 - hex bolt; 7 - screw for locking rotation; 8 - threaded plug; 9 - a sealing ring communicates with the bellows 9, which accumulates compressed air. The check valve 10 provides compressed air moving in one direction with a brake cylinder to the bellows and prevents air movement in the opposite direction. For the train braking, the crane handle for a driver 4 is transferred to the braking position, feed line 3 is disconnected and the brake lines 5 communicates with the atmosphere $A m$ through the valves 4 . When lowering the pressure in the brake line 5, the air distributor the air distributor 6 comes into effect, disconnects the brake cylinder 7 with the bellows 9 and combines it with a spare tank 8 filled with the compressed air. When applying compressed air in the brake cylinder 7 , the piston rod moves and transfers braking force through the longitudinal rod 13 to chuck mechanisms which force 14 brake shoes with the brake plate 15 against the brake disc 19.

Further on, the control valve 11 of the bellows 9 responds and the compressed accumulated air is fed under pressure into the hole 16 (Fig. 4) of brake pads 15 through a rubber pipe 12. This helps to cool the "brake pad - brake disc" contact.

A disc brake of a railway vehicle, which consists of brake discs, brake cylinders, brake pads, shoes, according to a prototype, is also developed, as well as a system of forced cooling of the frictional contact disc and pad with compressed air from the brake line. The technical result of the use of project equipment includes increasing the braking efficiency and reducing the intensity of

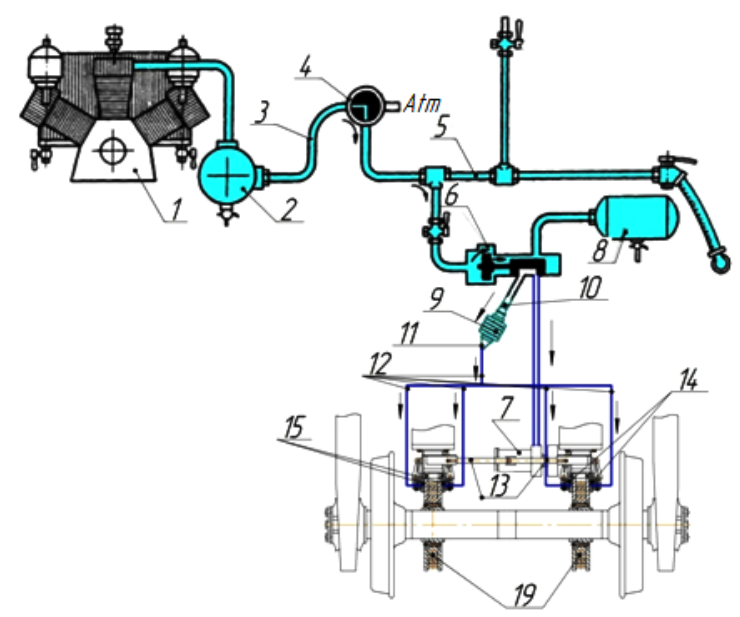

Fig. 3. Method of breaking a railway vehicle 


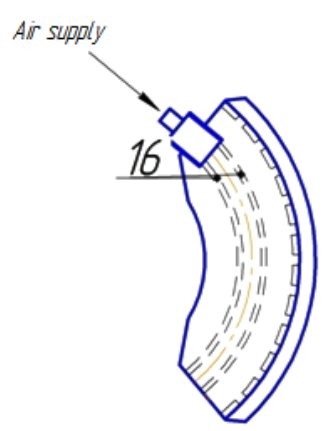

Fig. 4. Composite brake lining with holes

wear of brake linings through the timely removal of products of frictional wear of the friction zone, cooling of the zone of the frictional contact of "brake pad brake disc", improving traffic safety by increasing braking reliability.

When supplying compressed air between the brake linings and the brake disk during braking, one can identify the factors that will affect this process:

1. The air pressure supplied between the brake disc and the brake linings.

2. The diameter of the inlet openings of the fittings in the brake linings.

3. Optimal clearance between the brake disc and brake pads (before the braking process so that the air has time to blow off the pads).

The parameters governing the operation of the braking mechanism, when the compressed air is supplied between the brake pads and the brake disk, are as follows:

- air flow from the receiver;

- the coefficient of friction, the coefficient of efficiency and the coefficient of stability of the brake mechanism;

- the uniform distribution of air over the surface of the friction pad during braking;

- specific braking force.

In view of this, it is necessary to define and recommend the value of pressure of compressed air and the diameters of the inlet holes so that the force of counteraction from the compressed air does not lead to deterioration of the above parameters.

That is, it is necessary to determine numerically the factors that affect the process of supplying compressed air between the brake disc and brake linings during the braking process and the dynamics of their action.

In the case of forced cooling by compressed air, the surface of the brake lining should be considered as an aerostatic slip resistance. Its basis will be a friction pad with symmetrically located holes for the supply of compressed air, relative to the longitudinal axis.

The calculation of the aerostatic support is based on the approximation of the pressure field in the gap by difference algebraic equations. The method takes into account the two-dimensional distribution of the gas flow in the supports of different configurations and gives results close to the real ones. In each of the points, it is necessary to consider the integrated equations, using known formulas for the approximate calculation of derivatives.
There are several methods for supplying and distributing gas in the gap. A very effective one is the sectional system of gas supply with its distribution in the working gap on the micro cavities. The calculation scheme of a single-channel straight-line aerostatic support, applied with a guide width of less than $40 \mathrm{~mm}$, is shown in Fig. 5 .

The gas is fed to the pressure beanvironment. The microgroove, in combination with the stationary part of the support, forms a capillarring $\rho_{0}$. Passing through the hole of the submersible diameters $d$, the gas with pressure $p_{d}$ enters the micro curve length $l$; moving along the last, through the gap goes to the ey feeding channel having a split in the form of an equilateral triangle of height $t$ (depth of the groove). Due to the small amount of air flow that flows through the lubrication gap, the flow along the capillary can be considered laminar.

A more precise solution of the problem of laminar lubrication of the support is associated with great difficulty, since the flow of lubrication through the holespatial: the flow velocity, in addition to the constituent $\frac{\partial y}{\partial t}$, also has the component $\frac{\partial x}{\partial t}$. These components are proportional to the corresponding pressure gradients. The pressure gradient $\frac{\partial p}{\partial x}$ along the capillary is small in comparison with the pressure gradient $\frac{\partial p}{\partial y}$, from which it can be assumed that the flow along the $y$ axis is flat and directed perpendicular to the capillary axis. The current line received confirms the admissibility of such a simplification of the task.

Consider an element of the lubricating layer of width $d x$ and height $h$, located at a distance $x$ from the inlet. The gas flow through the separation of the capillary decreases with increasing $x$ due to leakage through the gap,

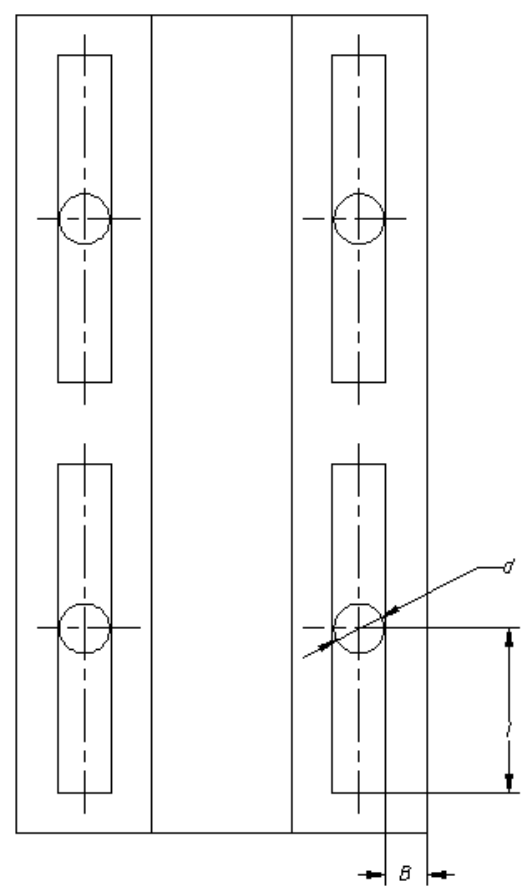

Fig. 5. Settlement scheme

ISSN 2071-2227, Naukovyi Visnyk NHU, 2019, № 2 
at $x=l$. Reducing the mass flow $d m_{x}$ on the segment of the capillary $d x$ should be equal to the mass flow through the gap (on both sides of the capillary) on the same segment in the direction $y$. This condition of continuity of the flow is used to construct a differential equation of support.

In the laminar flow, the volume flow of gas through a capillary with a transverse intersection of an equilateral triangle is associated with a pressure gradient formula

$$
q_{x}=-\frac{\partial p}{\partial x} \cdot \frac{\sqrt{3} t^{4}}{180 \mu}
$$

where $t$ is the depth of the microgroove; $p$ is changeable pressure in the channel; $\mu$ is the dynamic viscosity of the gas.

Fluctuations in temperature of gas during its slow flow along the capillary are insignificant; so there is a correlation

$$
\rho=A p,
$$

where $p$ is the density of the gas; $A-$ a constant.

Taking into account (1) and (2) the increase in the mass flow of gas along the capillary on the element $d x$ will be

$$
d m_{x}=\frac{\partial}{\partial x} q_{x} A p d x=-A \frac{\sqrt{3} t^{4}}{360 \mu} \frac{d^{2} p^{2}}{d x^{2}} d x .
$$

Because $\frac{\partial p}{\partial x} p=\frac{1}{2} \frac{\partial p^{2}}{\partial x}$.

The mass flow in the direction of the $y$ axis on the same segment equals the gain of the capillary in the direction of the $y$ axis

$$
\frac{1}{2} d m_{y}=q_{y} A p_{g} d x=-A \frac{h^{3}}{24 \mu} \frac{\partial p_{3}^{2}}{d y} d x,
$$

here $p_{g}$ - alternating along the axis y pressure in the gap; $\rho-$ pressure in the capillary.

Expression (4) is a linear differential equation of the first order

$$
\frac{\partial p_{g}^{2}}{\partial y}=\text { const }
$$

because $d m_{y}$ is a constant value for the intersection $x$. Its integration with allowance for the boundary conditions $p_{g}=p$ for $p_{g}=p_{a}$ for $y=B$ leads to the equation of distribution of pressure along the $\mathrm{y}$ axis

$$
p_{g}^{2}=-\frac{p^{2}-p_{a}^{2}}{B} y+p^{2} \text {. }
$$

Where

$$
\frac{\partial p_{g}^{2}}{\partial y}=-\frac{p^{2}-p_{a}^{2}}{B} .
$$

Substituting (6) in expression (4) we give the latter to the form

$$
d m_{y}=A \frac{h^{3}}{12 \mu} \cdot \frac{p^{2}-p_{a}^{2}}{B} d x
$$

The sum of elementary increases in costs in the direction of $x$ and $y$ should be zero. This condition leads to a differential equation

$$
\frac{h^{3}}{B}\left(p^{2}-p_{a}^{2}\right)=\frac{\sqrt{3} t^{4}}{30} \cdot \frac{d^{2} p^{2}}{d x^{2}} .
$$

Substituting the function $p(x)$ obtained in the equation (5) as a result of the solution of the last equation, we find $p_{g}=p_{g}(y)$.

Indicate the characteristic of a flat support with a microgroove

$$
K=17.3 \frac{l^{2} h_{0}^{3}}{B t^{4}}
$$

and dimensionless parameters: $P=\frac{p}{p_{a}}-$ relative pressure in the capillary; $X=\frac{x}{l}-$ relative coordinate; $H=\frac{h}{h_{0}}-$ relative clearance $\left(h_{0}\right.$ - estimated clearance).

In addition, we will denote the reduction of the record

$$
m^{2}=K H^{3}=17.3 \frac{l^{2} h_{0}^{3}}{B t^{4}} .
$$

The differential equation of pressure distribution along the capillary will have the form

$$
\frac{\partial^{2} p^{2}}{\partial X}-m^{2} P^{2}+m^{2}=0
$$

The general solution of this equation will be

$$
P^{2}=C_{1} e^{m X}+C_{2} e^{-m X}+1 .
$$

Taking into account the boundary conditions, $P=P_{d}$ at $X=0$ (at the exit of the throttle with a diameter $d$ ) and $\frac{\partial P}{\partial X}=0$ at $X=1$ (since the gas flow at the end of the capillary can be taken to be zero), we determine constant integration and find the law of pressure distribution along the length of the capillary

$$
P^{2}=\frac{\left(p_{d}^{2}-1\right) e^{m X}}{1+e^{2 m}}+\frac{\left(p_{d}^{2}-1\right) e^{-m X}}{1+e^{-2 m}} .
$$

The results of calculations by the equation (11), as well as the dependence of the specific rigidity of the resistance to pressure, are calculated and presented in the form of tables and nomograms.

For further calculations, a number of known parameters are given and the required ones are calculated. For the design brake pad we find an expression that determines the optimal hole diameter, depending on the pressure.

$$
d=\sqrt{\sqrt{\frac{K_{1} \gamma_{0}}{g}} \frac{t^{4}}{102 \alpha / \mu}}
$$

where $K_{1}-$ specific stiffness of the support; $\gamma_{0}-$ specific gravity of air at pressure $p_{0} ; t-$ groove depth; $\alpha-$ coefficient of production; $\mu-$ is the dynamic air viscosity. 
Fig. 6 shows the results of calculating the optimal hole diameter, depending on the pressure at different values of the length of the groove $l$. According to the data obtained, under the pressure of the air, which is fed into the holes of the brake lining up to $0.4 \mathrm{MPa}$ (pressure in the brake cylinder during braking of the car), the estimated diameter of the holes does not exceed $8 \mathrm{~mm}$.

It is also necessary to analyze the force of counter pressure, which is formed when compressed air is used to cool the frictional contact, and to classify the products of wear. It is calculated by the formula

$$
Q=p_{a} p_{0} B \ln K_{H},
$$

where $K_{H}$ is the specific strength of the counterweight. By varying the number of holes $n$, the geometric parameters of the element of the aerostatic support (overlays) and the pressure, different values of the force of the counterweight $Q$ can be obtained.

Fig. 7 shows a plot of the dependence of the uplift force $Q$ on the number of holes in one overlay. According to the formula, it is linear.

Fig. 8 shows the dependence of air flow rate on pressure during braking.

Depending on the force of pressing the brake linings on the axle and other parameters of the braking system, the parameters of the design brake lining are determined.

Conclusions and recommendations for further research. According to the results of the planned strategic

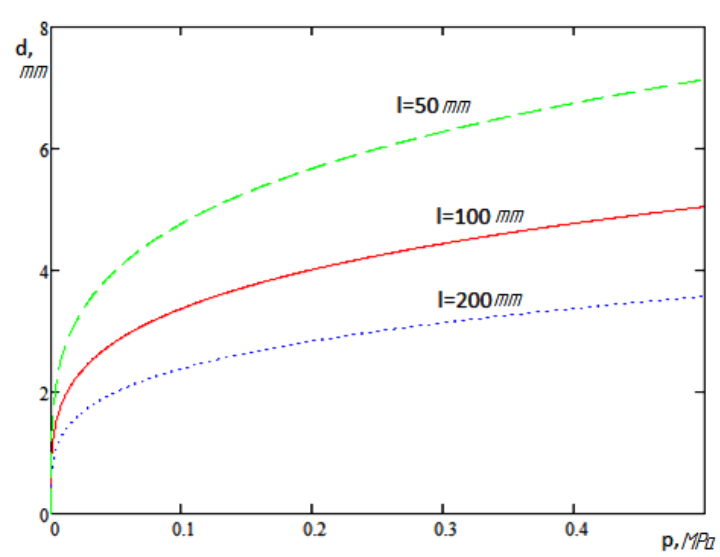

Fig. 6. Graph of the dependence of the optimal diameter of the holes on the pressure of air supplied to them

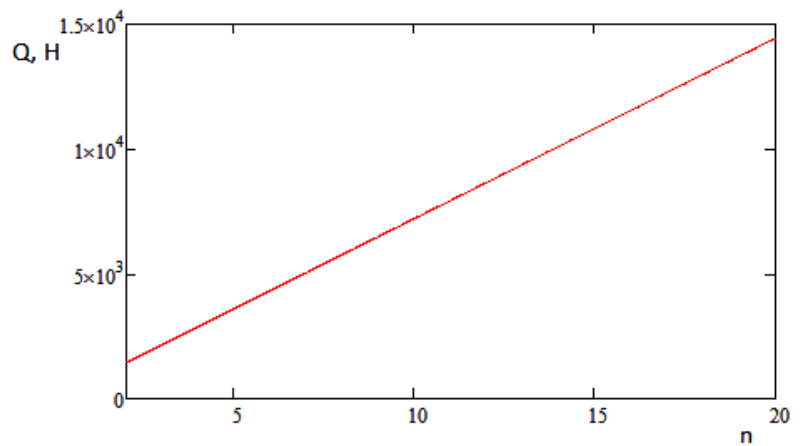

Fig. 7. The graph of dependence of the uplift force on the number of holes $n$ in one overlay

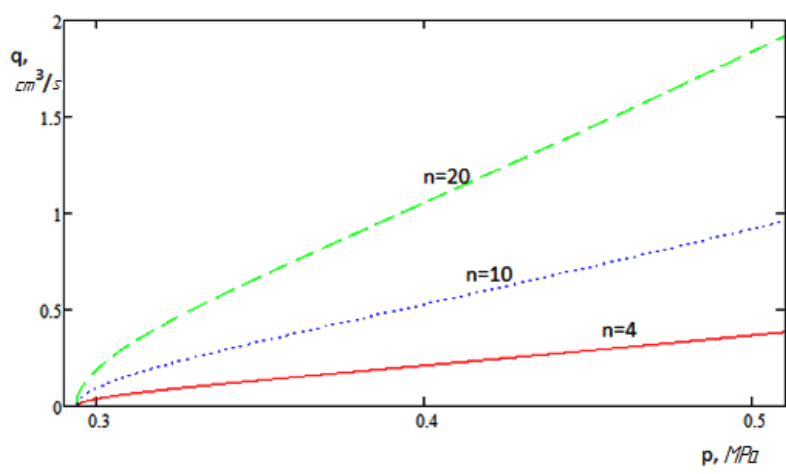

Fig. 8. Dependence of air flow rate on pressure

principles of the development of the world rail system, analysis of the expert survey of specialists of research organizations in the field of rail transport, increasing the efficiency of the operation of brake equipment is one of the most important factors for increasing the speed of traffic, safety and energy efficiency of rail transport.

An innovative method for controlling the temperature of brake friction surfaces is suggested, which will promote further development of high-speed locomotive movement. The method features the novelty of the developed solutions, is of theoretical and practical value regarding the improvement of the performance characteristics of brakes. For the proposed method, assessment of the influence of factors on the operation of the braking equipment during the supply of compressed air to the frictional contact is made. The scientific novelty of the research consists in the creation of a mathematical model of the dependence of the optimal diameter of the friction lining holes on the air pressure supplied to them, as well as the dependence of the air flow on the pressure.

Acknowledgement. This research was funded by a grant (No. S-LU-18-12) from the Research Council of Lithuania. This research was performed in cooperation with the Volodymyr Dahl East Ukrainian National University, Ukraine.

\section{References.}

1. Panchenko, S. V., Butko, T.V., Prokhorchenko, A.V. and Parkhomenko, L. O., 2016. Formation of an automated traffic capacity calculation system of rail networks for freight flows of mining and smelting enterprises. Naukovyi Visnyk Natsionalnoho Hirnychoho Universytetu, 2, pp. 93-99.

2. Gerlici, J., Gorgunov, M., Kravchenko, K., Domin, R., Kovtanets, M. and Lack, T., 2017. Slipping and skidding occurrence probability decreasing by means of the friction controlling in the wheel-braking pad and wheel-rail contacts. Manufacturing Technology, 17(2), pp. 179-186.

3. Yevtushenko, A. A. and Grzes, P., 2015. 3D FE model of frictional heating and wear with a mutual influence of the sliding velocity and temperature in a disc brake. International Communications in Heat and Mass Transfer, pp. 1-8.

4. Ghadimi, B., Kowsary, F. and Khorami, M., 2013. Thermal analysis of locomotive wheel-mounted brake disc. Applied Thermal Engineering, 51, pp. 948-952. 
5. Gerlici, J., Gorgunov, M., Kravchenko, K., Kostyukevich, A., Nozhenko, O. and Lack, T., 2016. Experimental Rigs for Wheel/Rail Contact Research. Manufacturing Technology, 16(5), pp. 909-916.

6. Tartakovskyi, E., Gorobchenko, O. and Antonovych, A., 2016. Improving the process of driving a locomotive through the use of decision support systems. Eastern-European Journal of Enterprise Technologies, 5(3(83)), pp. 4-11.

7. Myamlin, S., Lingaitis, L.P., Dailydka, S., Vaičiūnas, G., Bogdevičius, M. and Bureika, G., 2015. Determination of the dynamic characteristics of freight wagons with various bogie. Transport, 30(1), pp. 88-92. DOI: $10.3846 / 16484142.2015 .1020565$.

8. Lovskaya, A. and Ryibin, A., 2016. The study of dynamic load on a wagon-platform at a shunting collision. Eastern-European Journal of Enterprise Technologies, 3(7(81)),pp.4-8. DOI: 10.15587/1729-4061.2016.72054. 9. Kelrykh, M. and Fomin, O., 2014. Perspective directions of planning carrying systems of gondolas. Metallurgical and Mining Industry, 6, pp. 64-67.

10. Fomin, O., 2015. Improvement of upper bundling of side wall of gondola cars of 12-9745 model. Metallurgical and Mining Industry, 1, pp. 45-48.

11. Hauser, V., Nozhenko, O.S., Kravchenko, K. O., Loulová, M., Gerlici, J. and Lack, T., 2017. Proposolof a Mechanism for Setting Bogie Wheelsets to Radisl Position while Riding Along Track Curve. Manufacturing Technology, 17(2), pp. 186-192.

12. Adamowicz, A. and Grzes, P., 2011. Analysis of disc brake temperature distribution during single braking under non-axisymmetric load. Applied Thermal Engineering, 31, pp. 1003-1012. DOI: 10.1016/j.applthermaleng.2010.12.016.

\section{Концептуальні основи термокерованості в залізничних гальмових трибопарах}

\section{М. І. Горбунов ${ }^{1}$, О. В. Фомін ${ }^{2}$, О. В. Просвірова ${ }^{1}$, П. М. Прокопенко}

1 - Східноукраїнський національний університет імені Володимира Даля, м. Сєвєродонецьк, Україна, e-mail: gorbunov0255@gmail.com; prosvirova@ukr.net

2 - Державний університет інфраструктури та технологій, м. Київ, Україна, e-mail: fomin1985@ukr.net; prokopenko1520mm@gmail.com

У наш час проблема недостатньої потужності гальмування вирішується за рахунок збільшення кількості пар тертя, що призводить до збільшення ресурсу та трудомісткості, непідресорної маси, стійкості до руху й низької ресурсної ефективності. Також гостро стоїть проблема зниження рівня шуму при використанні фрикційних гальм. Аналіз проблем існуючого гальмівного обладнання призвів до вибору перспективного напряму досліджень ефективності гальмування - контролю температури гальмівних поверхонь тертя.

Мета. Створення способу підвищення ефективності гальмівної системи шляхом управління охолодженням поверхонь тертя адаптивною подачею повітря; створення математичної моделі подачі стисненого повітря до гальмівного фрикційного контакту для отримання оптимального діаметру отворів у накладках і відповідної продуктивності подачі повітря.

Методика. У ході дослідження проведено аналіз провідних сучасних досліджень і патентів технічних рішень, спрямованих на покращення фрикційних властивостей гальмівних пристроїв, методів теорії прийняття рішень і експертної оцінки методів підвищення експлуатаційних характеристик залізничних гальмівних систем. Застосоване математичне моделювання подачі стисненого повітря до зони відповідної фрикційної взаємодії.

Результати. Розроблена концепція адаптивного управління енергозатратами на самовентиляції гальмівного диска на удосконаленній математичній моделі, що враховує геометричні параметри повітряних трактів. Запропоновано метод оцінки впливу факторів на роботу гальмівного обладнання при подачі стисненого повітря на фрикційний контакт.

Наукова новизна. Полягає у створенні математичної моделі подачі стисненого повітря до гальмівного фрикційного контакту задля отримання оптимального діаметра отворів у накладках. Застосування запропонованого способу охолодження дозволить підвищити ефективність роботи фрикційних гальмівних елементів рухомого складу, збільшити коефіцієнт зчеплення, стабілізувати температуру у трибоконтакті, зменшити знос гальмівних поверхонь тертя та підвищити безпеку руху.

Практична значимість. У результаті проведеного комплексу досліджень уперше запропоновано й науково обгрунтовано метод адаптивного примусового охолодження поверхонь тертя гальма, що забезпечить ефективні характеристики процесу охолодження, дозволить істотно зменшити залежність коефіцієнта тертя від температури в зоні контакту робочих елементів при гальмуванні. Застосування запропонованих розробок дозволить:

- ефективно використовувати стиснене повітря, що вилучається із гальмівних циліндрів;

- охолоджувати зону контакту „гальмівні колодки - колеса“, „гальмівні колодки - диски“, подаючи стиснене охолоджене повітря в отвори гальмівної колодки;

- підвищити ефективність гальмування та знизити інтенсивність зношування гальмівних накладок унаслідок своєчасного видалення продуктів тертя із зони контакту;

- покращити безпеку руху поїздів за рахунок підвищення надійності гальмування.

Ключові слова: залізничний транспорт, термоуправління, дискові гальма, фрикційна взаємодія

\section{Концептуальные основы термоуправления в железнодорожных тормозных трибопарах}
Н. И. Горбунов ${ }^{1}$, А. В. Фомин ${ }^{2}$ О. В. Просвирова ${ }^{1}$, П. Н. Прокопенко ${ }^{2}$ 
1 - Восточноукраинский национальный университет имени Владимира Даля, г. Северодонецк, Украина, e-mail: gorbunov0255@gmail.com; prosvirova@ukr.net

2 - Государственный университет инфраструктуры и технологий, г. Киев, Украина, e-mail: fomin1985@ukr.net; prokopenko1520mm@gmail.com

В наше время проблема недостаточной мощности торможения решается за счет увеличения количества пар трения, что приводит к увеличению ресурса и трудоемкости, неподрессоренной массы, устойчивости к движению и низкой ресурсной эффективности. Также остро стоит проблема снижения уровня шума при использовании фрикционных тормозов. Анализ проблем существующего тормозного оборудования привел к выбору перспективного направления исследований эффективности торможения - управление температурой тормозных поверхностей трения.

Цель. Создание способа повышения эффективности тормозной системы путем управления охлаждением поверхностей трения адаптивной подачей воздуха; создание математической модели подачи сжатого воздуха в тормозной фрикционный контакт для получения оптимального диаметра отверстий в накладках и производительности подачи воздуха.

Методика. В ходе исследования проведен анализ ведущих современных исследований и патентов технических решений, направленных на улучшение фрикционных свойств тормозныхустройств, методов теории принятия решений и экспертной оценки методов повышения эксплуатационных характеристик железнодорожных тормозных систем. Применено математическое моделирование подачи сжатого водуха в зону соответствующего фрикционного взаимодействия.

Результаты. Разработана концепция адаптивного управления энергозатратами на самовентиляции тормозного диска на усовершенствованной математической модели, учитывающей геометрические параметры воздушных трактов. Предложен метод оценки влияния факторов на работу тормозного оборудования при подаче сжатого воздуха на фрикционный контакт.

Научная новизна. Заключается в создании математической модели подачи сжатого воздуха в тормозной фрикционный контакт для получения оптимального диаметра отверстий в накладках. Применение предлагаемого способа охлаждения позволит повысить эффективность работы фрикционных тормозных элементов подвижного состава, увеличить коэффициент сцепления, стабилизировать температуру в трибоконтакте, уменьшить износ тормозных поверхностей трения и повысить безопасность движения.

Практическая ценность. В результате проведенного комплекса исследований впервые предложен и научно обоснован метод адаптивного принудительного охлаждения поверхностей трения тормоза, что обеспечит эффективные характеристики процесса охлаждения, позволит существенно уменьшить зависимость коэффициента трения от температуры в зоне контакта рабочих элементов при торможении. Применение предложенных разработок позволит:

- эффективно использовать сжатый воздух, стравливаемый из тормозных цилиндров;

- охлаждать зону контакта „тормозные колодки - колеса“, „тормозные колодки - диски“, подавая сжатый охлажденный воздух в отверстия тормозной колодки;

- повысить эффективность торможения и снизить интенсивность износа тормозных накладок в результате своевременного удаления продуктов трения из зоны контакта;

- увеличить безопасность движения поездов за счет повышения надежности торможения.

Ключевые слова: железнодорожный транспорт, термоуправление, дисковый тормоз, фрикционное взаимодействие

Рекомендовано до публікації докт. техн. наук В.П.Ткаченком. Дата надходження рукопису 20.01.18. 